\title{
The Organic Food Philosophy: A Qualitative Exploration of the Practices, Values, and Beliefs of Dutch Organic Consumers Within a Cultural-Historical Frame
}

\author{
Hanna Schösler $\cdot$ Joop de Boer $\cdot$ Jan J. Boersema
}

Accepted: 22 March 2012/Published online: 8 April 2012

(C) The Author(s) 2012. This article is published with open access at Springerlink.com

\begin{abstract}
Food consumption has been identified as a realm of key importance for progressing the world towards more sustainable consumption overall. Consumers have the option to choose organic food as a visible product of more ecologically integrated farming methods and, in general, more carefully produced food. This study aims to investigate the choice for organic from a cultural-historical perspective and aims to reveal the food philosophy of current organic consumers in The Netherlands. A concise history of the organic food movement is provided going back to the German Lebensreform and the American Natural Foods Movement. We discuss themes such as the wish to return to a more natural lifestyle, distancing from materialistic lifestyles, and reverting to a more meaningful moral life. Based on a number of in-depth interviews, the study illustrates that these themes are still of influence among current organic consumers who additionally raised the importance of connectedness to nature, awareness, and purity. We argue that their values are shared by a much larger part of Dutch society than those currently shopping for organic food. Strengthening these cultural values in the context of more sustainable food choices may help to expand the amount of organic consumers and hereby aid a transition towards more sustainable consumption.
\end{abstract}

Keywords Organic consumption - Food culture - Sustainable development . Sustainable food choice · Human values · Worldview

\footnotetext{
H. Schösler $(\bowtie) \cdot$ J. de Boer · J. J. Boersema Institute for Environmental Studies, VU University, De Boelelaan 1087, 1081 HV Amsterdam, The Netherlands

e-mail: hanna.schosler@vu.nl

J. de Boer

e-mail: joop.de.boer@vu.nl

J. J. Boersema

e-mail: jan.boersema@vu.nl
} 


\section{Introduction}

Food consumption has been identified as an area of key importance if the world wants to progress towards more sustainable consumption (Carlsson-Kanyama and González 2009; Stehfest et al. 2009). In Western societies, such as The Netherlands, this implies a transition towards less animal-derived proteins (Aiking 2011; Reijnders and Soret 2003) and, in general, more carefully produced food. This transition will not be easy, however, because the relationships between food producers and consumers are bounded by many economic, cultural, and geographic constraints, and all food seems to be embedded in a contested discourse of knowledge claims (Goodman and DuPuis 2002). Moreover, to consumers, changes towards more sustainable food patterns seem only worthwhile when the changes not only enable their pursuit of lifestyles with a lighter environmental burden but are also perceived as rewarding (de Vries and Petersen 2009). Organic food has the potential to meet these demands because it is more sustainable (Badgley et al. 2007; Thøgersen 2010) and because it has become increasingly popular with consumers all over the world (IFOAM 2011). In order to fully utilize this potential, it may be necessary to better understand the cultural context of the choice for organic food, because the cultural changes that will be needed to shift towards a more sustainable society and associated food choices are profound (Aiking 2011). In the past, several marketing studies have been done to identify consumer segments where market share can be increased (Aertsens et al. 2009; Hughner et al. 2007). Within this line of research, however, it tends to be forgotten that the emergence of organic food is associated with reflexive consumption (Goodman and DuPuis 2002) and cultural changes in Western societies (Campbell 2007). Also, and of particular interest, organic consumers seem to refuse a passive role in the food system. Taking an active role may enable them to resolve the alleged contradiction between environmentally responsible behavior and a satisfying life (Brown and Kasser 2005), for example, by understanding themselves as part of a natural order (Taylor 1989). Hence, in the present paper we have chosen to put the cultural dimension of organic consumption central, because it may help to explain more in-depth what makes alternative food choices so valuable to these consumers. As Crompton (2011) argues, particular cultural values motivate people to express concern about a range of environmental and social problems, and such values are associated with action to tackle these problems. Our ultimate objective is therefore to derive insights that can facilitate the much needed transition towards more sustainable consumption patterns (Crompton 2011; Jackson 2005).

The approach on which our work is based can be characterized as an extended case study, which analyses the practices of particular individuals (i.e., the cases) in light of cultural patterns that have developed over several centuries. The purpose of this approach is to understand the case and its theoretical significance (Small 2009; Yin 2003). For theory development, a cross-case analysis involving about ten individuals may provide a good basis. A key theoretical concept in our understanding of the individual is the personal "food philosophy" that he or she might hold. A food philosophy refers to a cluster of practices, values and beliefs that evolves over a long period of time within a particular cultural context and is shared 
on a collective level. The notion of a food philosophy is inspired by the concept of a worldview (Naugle 2002) or an inescapable framework (Taylor 1989). These concepts refer to the cultural backdrop against which people orientate themselves on questions of what is good, valuable, admirable, and worthwhile (Hedlund-de Witt 2011). This backdrop, however, is largely implicit and unarticulated, and people may be unaware of its influence or even resist it (Taylor 1989). However, through the interpretation of empirical interview data, one can uncover an underlying coherence or sense that can generate a better understanding of important dimensions of human life (Taylor 1971). Based on the literature, we will explore the food philosophy of the organic movement by providing a concise historical and cultural background. To analyze the personal food philosophies of current organic consumers, we will present findings from qualitative interviews conducted with individuals in The Netherlands.

The interviews were conducted in 2010 as part of a bigger project that investigated food practices, values, and beliefs among the Dutch population. The case selection was based on the sampling for range approach, in which the researcher identifies subcategories within the study's population and interviews a given number of people in each subcategory (Weiss 1994). The subcategories were delineated according to the different food-related orientations identified in previous survey research (de Boer et al. 2007). The representative survey among Dutch citizens indicated four distinct value-orientations towards food based on the degree of involvement with food and a motivational focus on promotion versus prevention. ${ }^{1}$ For our research, we focused on the "reflective" orientation, which entails a careful and mindful use of food and a preference for responsible products (i.e. high involvement combined with a prevention focus). The organic consumers were selected to represent this orientation towards food. According to the survey results, the "reflective" orientation can be found among roughly $14 \%$ of the Dutch population (de Boer et al. 2009). As mentioned before, however, the present study does not search for statistical significance, but for theoretical significance. A more qualitative, interpretive approach is needed in order to reveal greater depth and meaning of consumer practices (Hughner et al. 2007). By combining insights into the cultural dimensions of the organic movement with insights into the individual's motivation for using organic products, we will try to facilitate a more complete understanding of these consumers' practices, values and beliefs and the potential influence thereof on a more sustainable diet-more precisely, a diet less reliant on meat.

In sum, the present paper is organized into three sections. First, it provides a concise cultural background of organic food. Next, it presents the results of a qualitative interview study with consumers of organic food in The Netherlands.

\footnotetext{
1 Promotion and prevention are key concepts of Higgins's psychological motivation theory (Higgins 1997), generally, a promotion orientation makes the person sensitive to gains, accomplishments, and advancement needs. In contrast, a prevention orientation makes the person sensitive to safety, responsibility, and security needs.
} 
Finally, the paper discusses the overall relevance of our findings in the context of the transition towards a more sustainable food system.

However, before moving on, we briefly reflect upon the assumption made above that organic food consumption is indeed part of a more sustainable diet that benefits social and environmental systems as well as human health (Lang and Heasman 2004). Organic farming is defined as a holistic production management, which promotes and enhances agro-ecosystem health and avoids the use of synthetic materials to fulfill any specific function within the system (Codex Alimentarius 1999). Furthermore it adheres to the principle of health as a state of holism, self-regulation, regeneration, and balance and is exemplified by Lady Eve Balfour's quote "healthy soil, healthy plants, healthy people" (IFOAM 2011). Despite these desirable goals, there has been some controversy about the degree to which organic production can contribute to sustainability, given the increased amount of land that organic production requires at the cost of nature reserves (Tilman et al. 2001) and the arguable benefits in terms of biodiversity (Hodgson et al. 2010). On the other hand, it has also been shown that organic agriculture is capable of feeding the world sustainably (Badgley et al. 2007), especially if farming practices that mitigate climate change are also sufficiently employed (Badgley and Perfecto 2007; Scherr and Sthapit 2009). In considering the market of organic food, however, fundamental contradictions have been identified between mainstream agro-industrial and alternative movement conventions, because increases in scale and standardization lead to the bifurcation of the organic sector and the watering down of its original values (Buck et al. 1997; Constance et al. 2008). Thus, a globalizing organic agro-food sector risks susceptibility to similar ills it aimed to cure in the first place (Raynolds 2004). For instance, although it is debatable whether organic agriculture as a whole is becoming conventional, there is a growing influence of conventional agro-food commodity chains in certain sub-sectors of organic agriculture in The Netherlands (de Wit and Verhoog 2007). While acknowledging that trends towards conventionalization in the sector and the development of an organic industry add another set of problems to the sustainability debate, it is crucial to also note the sector's role in society. At the very least the trend towards organic can be seen as a valuable driving force that stimulates conventional agriculture to adopt more ecologically integrated methods and inspires consumers to adopt new values and ideals that can give direction to more sustainable food practices (Lang and Heasman 2004). The consumption of organic food has also been discussed in the context of a shift in worldviews that is taking place in the West (Campbell 2007). According to Campbell, healthy and environmentally-friendly food consumption is something that is perceived as deeply satisfying and meaningful. The choice for organic food may have an underestimated religious undertone, providing people with purpose in life and a means to reconnect with nature (Campbell 2007; Pilgrim and Pretty 2010). Such orientations towards food may be understood in the context of contemporary spirituality and can have an important role in facilitating the transition towards a more sustainable society (Hedlund-de Witt 2011). It is the food philosophy associated with the trend towards organic that we are particularly interested in. 


\section{A Concise Background on the Organic Movement}

To gain insights into the cultural dimensions of the organic movement, a two-step research approach was used. In the first step, we identify long-term trends in Western culture that have shaped the origins and the development of the organic and natural foods movement. It should be emphasized, however, that it is not possible within the scope of this paper to give a complete and historically accurate description of these topics. In this exploration, we had to limit ourselves to highlighting some major themes. Food has always been an important symbol that can reveal what conceptions of nature our culture affords and how people might derive identity from it (Douglas 1966; Fischler 1988; Montanari 2006). Specifically, we used philosopher Charles Taylor's acclaimed Sources of the self: The making of the modern identity (1989), because it provides a solid background on the development of Western culture and addresses in depth how changing patterns of thinking affected our conceptions of nature and the natural. The second step of our approach summarizes the history of organic food since the nineteenth century. In bringing together these particular works on culture and food, we tried to identify those cultural ideas that distinguish organic consumers and characterize their lifestyles.

In Sources of the Self. The making of the Modern Identity, Taylor suggests that modern Western culture, even though it is now characterized as fragmented and pluralistic, builds essentially on two divergent cultural orientations. These orientations are highly relevant to understanding alternative food philosophies. They can be loosely tied to the period of Enlightenment in Western history and the Romantic era. The Enlightenment inspired patterns of thought that emphasize a rational understanding and scientific reasoning about reality, which implies abstraction and objectification of the world and the natural phenomena one can observe. In this sense, it broke away from the mystical understanding of nature that used to be dominant prior to the Enlightenment (Glacken 1967). Nature, which includes the human body, is understood by constructing a correct representation of it in one's mind, thus making it a neutral object to observe and study (Taylor 1989). This implies that nature has no meaning beyond its function and a value that is only dependent on utility. Reason empowers people to study and observe the natural world, which in turn can lead to ideas that nature can be controlled and manipulated. Taylor (1989) argues that this objectification and instrumentalization of nature leads to a separation from nature and our moral independence from it.

Partly as a reaction to the instrumentalization of nature, Taylor (1989) argues that Western culture turned to creativity, intuition, and expressivity as a means to re-unify with nature. Mankind is then seen as an integral part of a larger order of living things that nourishes human life and creates bonds of solidarity within a mutually sustaining web of life. Even though Romantic religions of nature have died away, Taylor (1989: 384) argues that "the idea of being open to nature within us and without is still a very powerful one that is grounded in the understanding that mankind is part of a larger order of living beings, in the sense that their life springs from there and is sustained from there." This more embodied orientation towards nature inspires thinking that people should be careful and try to do no harm to 
nature. In this perspective, or even "way of being," nature is included in people's representations of self (Schultz et al. 2004), and forms a part of their identities. As a result, modern culture is characterized by the tension between the two big constellations of ideas (i.e., Enlightenment and Romantic views), and this tension becomes particularly manifest in the form of controversies about sustainability issues (Taylor 1989).

The divergent cultural ideas are also directly reflected in the history of organic food. While nowadays there is a more prominent link between the organic movement and environmental activism forming in the late 1960s (Foss and Larkin 1976), the roots of the organic movement actually run deeper. Ideas around organic farming developed almost independently in German and English speaking countries about a century ago. In Germany it was part of an influential movement that became known as the Lebensreform and consisted of various Reform movements resisting increasing industrialization, use of technology, materialism, and urbanization that were shaping a new way of life. The Reform movement promoted the return to a more natural way of living that consisted of vegetarian diets, physical training, natural medicine and going back to the land (Vogt 2007). Food was important due to its direct link with the natural environment, the agriculture's dramatic mechanization and industrialization, the loss of rural lifestyles and the associated selfsufficiency and independence (Vogt 2007). Countries undergoing similar changes in the food system, such as Germany, The Netherlands, England and the United States, all exhibited cultural responses similar to the Lebensreform (van Otterloo 1983). The Dutch Reform movement was directly triggered by the developments taking place in Germany (ibid).

Many people perceived the dramatic societal changes and the loss of traditional rural lifestyles as a threat to their moral independence. A self-regimented way of living and control over one's body were symbolic in averting this danger (Barlösius 1997). The Reform movement was therefore associated with a moderate, sometimes ascetic lifestyle. It enabled the individual to feel self-determined and to live according to one's own moral and ethical principles, independent from behavioral prescriptions of government and industry. For example, the use of processed food products was avoided on these grounds. Due to its visibility and daily practice, food consumption was an exceptionally suitable domain for individuals to express their commitment to an ethical and self-determined lifestyle purely founded on one's ideals (ibid).

Vegetarianism was an important part of the lifestyle promoted by the Reform movement (Barlösius 1997), as the consumption of meat is traditionally a morally contested practice (Fiddes 1991). Followers also turned against products of the upcoming food industry and banned instant or canned products. Also, natural stimulants, such as tobacco, coffee, alcohol, sugar, and strong spices, were rejected. Instead, raw vegetables and whole-wheat products were preferred (Barlösius 1997). The essential question raised by the reformers was how human needs in general should be satisfied, which explains why the movement was equally concerned, for example, with housing, clothing, and sexuality. The human body was conceived as a nexus of the individual's needs and the constraints of the societal system. 
Gusfield (1992) describes cultural changes very similar to the Lebensreform associated with the American "Natural Foods Movement." The movement had its origins in the $1830 \mathrm{~s}$, a period of intense religious reawakening and deep concern over the immorality and crime associated with increasing urbanization and the loss of traditional bodies of authority. One of the key reform thinkers was Sylvester Graham, a Presbyterian minister. He opposed modern food technology and considered the unrefined, the coarse, the pure, and the raw to be healthy qualities while the refined, the smooth, the processed, and the cooked, respectively, were objectionable (ibid). He dismissed refined white bread, the icon of the upcoming food industry, because it had less fiber than the common whole-grain breads and was baked outside the home. Stimulating foods, such as meat, coffee, sugar, or alcohol, were equally abject because they were believed to excite the body in an unhealthy manner, just like sexual desires would. What characterized the philosophy was the capital importance of self-discipline and self-control against the temptations surrounding the individual.

The various organic and natural foods movements were not very successful until the 1960s. It was the publication of Silent Spring by Rachel Carson (1962) that became a turning point for both the modern organic and environmental movement (Kristiansen and Merfield 2006). Silent Spring brought a whole new set of arguments against industrial farming, in addition to those that the organic movement had been pushing for many decades. Several new movements took up the moral stance towards food and continue to promote a more vegetarian diet and consumption of organic food. Hamilton et al. (1995) suggest that this food "alternativism" is often associated with New Age philosophy and a spiritual worldview (see also: Hedlund-de Witt 2011). In fact, various studies claim that natural and health foods can be viewed in a spiritual context (Campbell 2007; van Otterloo 1983, 1999) and can be linked to spiritual practice, such as mindfulness meditation (Jacob et al. 2009). From the very beginning, spirituality was also incorporated in the Lebensreform by reformers like Rudolf Steiner, who laid the spiritual foundations of organic farming (Kirchmann et al. 2008). The steady popularity of his esoteric philosophy, Anthroposophy, illustrates that the movement is still influential today. Nevertheless, people can also identify with "eating green" for more secular reasons (Jamison 2003). The same is true for the feeling of connectedness to nature (Hyland et al. 2010).

In summary, the insights provided above highlight a number of themes that may explain why organic consumption has been characterized as part of a distinctive way of life (Schifferstein and Oude Kamphuis 1998). These themes include a strong resistance towards food industry and technology, because they were perceived to impose consumption patterns that conflict with particular moral norms. Instead, people tried to conserve their independence and self-determination by orienting towards nature within as a source of morality. The inward orientation of their philosophy often led to spiritual associations and a belief that human needs are not only satisfied by material needs. Self-determination was associated with the practice of a moderate lifestyle - the (partial) abstinence from meat and other "unnatural" foods. In the following section, we compare these insights with the food philosophies of contemporary organic consumers by discussing a cluster of themes that emerged from the interviews we conducted with consumers in The Netherlands. 


\section{Food Philosophies of Current Organic Consumers}

In this section we move on to the findings from the interviews. Using the sampling for range approach (Weiss 1994), we contacted 33 people via different avenues. 13 of them were assigned to the subcategory of organic consumers. Organic consumption in The Netherlands is growing steadily, but is still rather low, compared with other European countries (Bakker 2011). The total market share in The Netherlands in 2009 was $2.3 \%$ (ibid). Roughly one-third of organic food is sold at specialized organic stores. ${ }^{2}$ As we were interested in consumers who are relatively highly involved with food, we secured interviews with ten people we approached in organic stores in two Dutch cities, Amsterdam and Groningen, the former a more metropolitan, big city and the latter a more rural, small city. Other subcategories of participants were acquired from a hobby-cooking club, the Slow Food organization and at regular supermarkets. The data used in this paper come from the participants approached in the organic shops; other participants that mentioned they regularly use organic food were also included. Altogether 9 women and 4 men participated, varying in age from 18 to 76 . Given that women shop more often in organic shops (Hughner et al. 2007), this distribution is acceptable; even so, women were also somewhat more willing to participate. The participants' level of education was relatively high (ten had graduated from university), but they were not particularly wealthy. About half of them were self-employed and had an artistic or creative background. It seemed that their daily routines were comparatively flexible, enabling them to visit farmers' markets during the day or prepare a midday meal at home.

The interviews were introduced as a study on food practices in The Netherlands. There was no prior mentioning of themes relevant to the objectives of this study, such as environmental sustainability or organic food consumption. The researchers engaged participants in conversations aided by some simple questions asking them to describe what they had eaten the day prior to the interview, how they had prepared their meals, and how they shopped for food. These questions were only meant to start the conversation, and participants were allowed to develop their own stories from there, introducing topics that were relevant to them. The interviewers limited their interference to posing questions, inviting participants to further engage in topics that they had brought up. The conversations lasted roughly an hour and were held, if possible, in participants' homes or, otherwise, in a public space. They were taped and transcribed verbatim. The real names of respondents are not provided to ensure their anonymity.

The interviews were analyzed according to the grounded theory approach (Charmaz 2006). This approach encourages the researcher to learn what participants' lives are like and to be sensitive to how they explain their statements and actions. Subsequently, she constructs a theory that is "grounded" in the data, instead of using preconceived, logically-deduced hypotheses (Glaser and Strauss 2009). The analytical process involved coding the interview material and constructing

\footnotetext{
${ }^{2}$ We refer here to stores that sell the majority of their goods with organic, fair-trade or bio-dynamic certification. They typically also store Japanese foods and health food supplements.
} 
conceptual categories from the emerging codes. The analysis of the interview data gave rise to three analytical themes that shed light on the food philosophies of organic consumers in The Netherlands. First, we discuss participants' feeling of connectedness with nature. Second, we discuss the notion of awareness. Third, we explain the value of purity.

\section{Connectedness with Nature}

Participants expressed a philosophy of "doing what feels natural." Their concern for the naturalness of food made the choice of organic and seasonal foods attractive. They described feeling connected with nature, which triggered feelings of care and responsibility for animals and the natural environment. Nature, however, was not perceived as a separate entity. Rather, participants felt an integral part of nature. Care for nature, therefore, also meant to care for one's physical and mental health, as well as striving for vitality and overall well-being. For example, participants expressed their sense of connection by expressing how season changes and other natural processes correspond to changes in their physical and mental constitution, such as the following participant.

At the farmers' market, there's a clear offer of the season [...] I find it interesting to do something with the cabbage the moment it's there in wintertime, because I find it fits with the moment, because I have different needs and, then, I like to eat differently. (Mary)

Through their connectedness with nature, participants explained their discovery of the various interdependencies of food and nature. They also became aware of the farmers that farm their vegetables, and they became more sensitive to the issues of familiarity, trust and geographical vicinity.

Vegetables I buy organic. I have a veggie box. [...] To me it's important that it's farmed with care and that it has travelled as little as possible. And that it's as seasonal as possible, that it comes from a familiar environment [...] I try to think about the consequences of my consumption for the rest, for the environment [...] I think, first came the environment and gradually I've created a connection with the farmers, because it's nice that he knows about us, and you see him every week, and now there is a strong social tie. (John)

One participant, who was also a practitioner of Japanese yoga, explained that it is part of her food philosophy to eat food that is native to her home region and seasonal. She explained that the natural environment influences her inner constitution, and the consumption of food is a vital mediator in this. As various foods have different effects on the body, her goal is always to achieve a balanced constitution by matching the food she selects to the needs of her body. The participant described how she uses her feeling and intuition to access this source of knowledge.

Your constitution is also partly a result of the weather or the water that you drink. The vegetables that grow here in wintertime, like root celery, are typically warming vegetables. So, that's perfect, because that's exactly what 
we need then. So, it's natural to eat what's in season here and now [...] I grow physically and mentally stronger, simply because I eat the food that's compatible with my momentary constitution. [...] I eat based on my perception of my own body [...] It is very intuitive, actually. (Katie)

Another participant, who felt inspired by ideas from the macrobiotic and Chinese food philosophies, described a similar connection and a longing for a more intuitive relationship with nature. She argued that people have lost part of their connectedness to nature and, thus, also their intuition about what is the right way to eat.

The philosophy is that you're one with the cosmos, with the environment. So your food should be seasonal [...] and you try to eat the food that belongs with the climate you live in. I'm not so strict.

When asked why this philosophy appeals to her, she replied:

I like its intangible character. Centuries back, humans had to live with nature; they were dependent on it and adapted to it completely: with the seasons, with the moon. And all this knowledge has been lost. [...] In China it's still more alive, but Europeans also had it. [...] It's a certain feeling about how things need to be done that you cannot explain. But, in our society, this feeling with nature and your environment has weakened. I find it really interesting to try and get [this feeling] back. (Sally)

The connectedness with nature was also evident in people's concern for animals. All participants watched their meat consumption closely and had considerable concern about animal welfare and the inhumane treatment of animals in the agricultural industry. Most of them were or had for periods in their lives been vegetarians. All reported cooking vegetarian food regularly, as well as frequently buying organic meat-meat that is produced in a more responsible manner. If they find buying organic meat too expensive or if it is unavailable, they prepare vegetarian meals. Participants felt that they should eat meat in moderation, and they often doubted the healthiness of regular meat consumption. On top of this, animals were generally seen as sentient fellow creatures with a right to live under natural circumstances, such as those organic farms try to provide. Therefore, the consumption of organic meat was an acceptable alternative for participants. They strongly opposed intensive livestock farming systems, because, to them, the animals are treated like a commodity.

I don't like the fact that animals are seen as products. Maybe that's not the worst... but I think you have to treat animals differently from a bag of cookies. It's hard to explain, but it just feels wrong to me. (Lauren)

We do eat meat, but not regularly. And if we do, it's always organic. [...]

What I find really important is the care for the animal. (Mary)

\section{Awareness}

Cooking and eating, especially with family and friends, were often described as a crucial moment of tranquillity and awareness in a busy life. Participants associated 
the moments that they can engage with food with a sense of well-being and happiness. They described their enjoyment in focusing on activities such as the food preparation, setting the table, making the plates look attractive, and eating the food. To them, these moments are in contrast to other daily activities, in which they often feel rushed and superficially engaged. Participants described a heightened awareness of their surroundings, as well as an awareness of their feelings and emotions.

I feel happy when I cook, when I have the time to do that [...] Enjoying is not only related to food, though, it's more about what happens here around me. In the evening I have the sun here and then, in combination with being outside, the tranquillity. Sitting here at the table and simply eating something tasty, that's what makes me happy. [...] To me, that's the ultimate pleasure: to find the peace and time to have awareness for that. (Mary)

It has a lot to do with attention and love. [...] I try to really make contact with food. (Emmy)

It can be really nice to enjoy food together, but I can also do it alone: when I'm really in the moment and enjoy what I eat or what I do in that moment, without really thinking about it. I mean, my head's always occupied, so I really enjoy when there are no thoughts, when I'm fully engaged in the moment. Of course, it should be a pleasant moment. Yes, that gives me peace and relaxation. (Lauren)

As these participants describe, their moments of awareness and attention to food were often qualified by the absence of thought and a feeling of being immersed in the activity of cooking or eating. This engagement and intense experience of the moment was something that fulfilled them with joy and peace. As the participant describes in the second quote, she establishes a sense of connection with her food by giving it attention.

Participants' awareness of the present moment made the entire context of a meal more salient. They experienced the sensual qualities of a meal: what the food looks like, what it smells and feels like, and what are the particular circumstances of the moment. All these factors contributed to the satisfaction they could derive from a meal. Likewise, they reported that their enjoyment of food was hampered when there was no time to pay attention.

What I really hate is rush. If there's rush, then all enjoyment is gone. That's really important. Then you don't see things anymore and you don't taste them anymore. (Thomas)

Engaging with food is the ultimate enjoyment for me, to find the tranquillity to have awareness for it. And stress or unhappiness I associate with having to eat an instant pizza, when I have no other choice. (Mary)

A heightened sensitivity to how one's body responds to food was also a dimension of participants' awareness. They frequently stated they rely on their senses to tell them what food they should eat. They listened to their bodies, when they wanted to find out how they should eat to feel good. 
For a few years I didn't eat meat. I didn't react well to it, so I changed my food pattern. I felt better [...] I noticed that my body responds in a certain way to everything I eat. So, if you eat something and it gives you stomach ache, you don't want to eat that anymore. (Mary)

You adjust what you eat to your constitution [...] you judge your constitution by sensing what food does to you. So, if you take the energy from food, if you feel that something warms you up, you get a warm tummy, or often I notice my hands getting warm. (Katie)

This heightened awareness also included sensitivity towards one's emotional responses. Participants described how particular food-related experiences-either pleasant or disturbing - made such a profound impression on them that they had a sustained influence on their food practices.

I visited a slaughterhouse a few times when I was 16. I have two uncles who are butchers. I saw how the cows got a pin shot in the head and the pigs were electrocuted so quickly and immediately hung on the hook while all is still moving. That gave such an impact that shortly after I stopped eating meat. (Thomas)

I used to have a Scottish boyfriend. He made a lot of things himself, baked his own bread, all very idyllic. He was a fisherman by profession and through him I saw and learned about the fish, about the sea, about the salmon, the fish farms and the consequences [...] and I guess because of him, for me now the only alternative is to choose organic meat and sustainable fish. It's got to do with being engaged with your personal environment, what happens around you. (Mary)

There seemed to be a link between awareness and the intensity of memories that people described in relation with food. All participants had vibrant memories of formative experiences related to food, which they described in colorful details. Obviously, food consumption was often intimately tied to their emotional experiences and, therefore, left a deep mark on their memories.

\section{Purity}

Participants had developed particular strategies to decide how to eat and what is good to eat. Central to these strategies was the participants' self-determination and the idea that they behave according to their personal values and their individual intuition. They tended to have the opinion that "we" don't know what we are eating because food producers mix substances together and thereby obscure people's choices. Since it has become extremely difficult for consumers to judge the quality and composition of the food they buy, participants categorized food according to their understanding of purity (and related concepts, such as simple, basic, whole, and raw). In what follows, we scrutinize in more detail what participants meant by these qualifications and how they enacted them in their practices. Purity was associated with food in a material sense, but also in an immaterial sense, as it referred to the moral purity of a particular food choice. 
I like my food to be pure. I cook with few spices, so that the original taste of the product is preserved. The product remains itself, and you can really taste it. (Thomas)

I used to put too many things together, and then you don't taste the pure flavour. So, I went back to cooking pure food. I never buy instant stuff. If I prepare a sauce, I simply start from scratch-that's more pure [...] As soon as I lose myself in all kinds of ingredients that I don't understand, the more processed things are, the further estranged from the original product, the less attractive I find them to be. (Mary)

Participants associated purity with making sure that the essence of the food is preserved. Thus, authenticity and originality were important, in terms of sensual food qualities like taste, appearance, smell, and feel. To preserve this essence, participants kept meals simple and ingredients few. Excessive use of spices, for example, was believed to obscure the true identity of the food. As the second citation illustrates, preparation from scratch was also important, as it helped participants to be aware of all ingredients. Therefore, when shopping, participants searched for raw foods, and they avoided processed foods, which were associated with artificial preservatives, chemical residues, E-numbers and added sugars. Also, the number of ingredients in a product served as an indicator of its purity.

For example I don't like instant yoghurts with readily added fruit and whatever ingredients there might be. I simply buy plain yoghurt, and then I add whatever I want to add. So, I know what I add. Pure... I prefer to buy the basics and then I'm in charge of mixing things. (Mary)

Another participant described the difference between the food that simply fills up the body and the food that really has the ability to nourish. He preferred foods that he considered whole and complete in terms of nourishment.

For instance, I hardly go for Chinese take-away. You're stuffed with feed rather than food. You get lots of rice, a tiny bit of vegetables and proportionally lots of meat.

When asked what distinguishes "food," he replied:

Well, food is the things that take some time to eat and digest, so whole wheat products, rye bread, vegetables, meat, not the things that disappear quickly. (Peter)

To him, the quality of food was expressed in the amount of time that was needed to eat something, as well as the length of time that he felt satisfied afterwards.

Another strategy to preserve the purity of a food is to try and preserve its natural appearance and form.

I like to serve all ingredients of the meal separately, so that they are visible $[\ldots]$ you see what you eat, nothing is hidden [...] no ornaments or additions that have nothing to do with the original product. (Thomas)

Also, when I have visitors, I don't serve everything hustled in a big pan, but I put things separate. So you can take what you like. Straightforward, 
elementary, and the food recognizable. I prefer that nothing is hidden! (Helena)

When I say fresh, I don't just mean the due date, but also that it's not in cans. I want to pick the food myself; I have to see it for myself. [...] I think it's really important to touch the food [...] that's why I don't buy canned food; you just can't see it properly. (Sarah)

Participants contrasted "pure," "fresh," "simple," "basic," "plain," "original," or "organic" foods with "estranged," "processed," "instant," "complex," or "canned" foods. One participant explained that these categories of food reflect not only material qualities of food, but are also associated with her moral beliefs regarding what is a good way to live:

When I talk about unsprayed and organic, I mean something more archetypal, more natural. I feel that we are pushed into more and more artificial circumstances in our society. We're on the wrong track. I think these values that I talked about, just now, awareness, understanding what you need. Of course, one person can need something more than another person, even with food. I mean, some people have the need to travel around the world and then they should do that. But let's be honest, many people don't have that 'need' they only do it because everybody's doing it. I like when people really work out for themselves, thinking independently, what they actually need. (Emmy)

Thus, the immaterial quality of purity was associated with living a reflective life in which one would try to be modest and sensitive to one's own needs. This idea was also expressed repeatedly in the importance that participants attributed to temperance. Temperance was perceived as a means to be self-determined and to make choices according to one's personal values. For example, participants wanted to express gratitude and respect for food, especially when consuming foods originating from animals.

People have so many desires they want to satisfy immediately, but tasting is important. I mean, a fish has also been an animal; you don't just wolf it down. You have to have some respect for it. That's the kind of temperance we search for. [...] My daughter has a different attitude. [...] She wants instant satisfaction. And if she's hungry, something needs to be done about it, immediately. She's not engaged with taste. (Thomas)

Underlying this temperance was the wish to transcend the bodily desire to eat and to appreciate food on an immaterial level. Part of the enjoyment of food was, therefore, contemplating the meal more fully. This partial shift from the material to the immaterial dimension of food was also represented in the shift of attention from quantity to quality.

To eat organic meat reflects also my conscious choice to consume less, but better quality. It's expensive and that's why I don't eat meat two days a week. That's all connected. So I think you can't view it separately [...] and at the end of the week, I've spent the same amount as I would otherwise. (Michael) 
Participants related temperance in their personal food consumption to the boundlessness and overconsumption that they perceived to be the current cultural norm, from which they wanted to distance themselves. The practice of temperance represented to them a shift away from desires and wants and towards their basic needs.

It feels best to me to use just what I need. All this excess and overkill that is the norm now doesn't appeal to me [...] What we often do, when we have leftovers, we eat it one day, skip one and then eat it again [...] I find it a sign of no respect to throw out food. (Emmy)

I think we [Dutch society] have an enormous overconsumption. We use much more than we actually need. (Lauren)

I buy what I need and try not to be manipulated by all the advertisements and special offers [...] this is what I see many people do: 'it's on sale, so I buy it.' But then at the end of the week, things are past the expiry date and are thrown out. That's a shame. (Peter)

This massive animal industry, I think it's appalling [...] Raising production is an end in itself! People have to buy different clothes every year, because of fashion, because of the economy. It's insane. (Helena)

These quotes illustrate that participants' particular food choices were associated with a rather critical view of society. They objected to the orientation towards consumerism, and they wanted to resist the manipulative influence of advertising and fashion. The practice of temperance was associated with an orientation inward, towards one's personal needs, that helped participants maintain an intuitive balance. They referred to the importance of being aware of one's body in order to assess the boundaries of what is enough and what is good to eat. This is also tied to the awareness that we described in the previous section.

I believe you have to eat moderately and healthy [...] I think when you are moderate then you don't fluctuate in weight and in how you feel physically.

There is a kind of stability in it. (Theresa)

\section{The Organic Food Philosophy and its Relevance to Sustainability}

Based on the history of the organic movement and personal stories of current organic consumers, we can highlight some key elements of the organic food philosophy. A central element of the stories was an intuitively felt connectedness with nature that goes beyond their care for plants and trees. It concerns a reflexive relationship with one's inner nature that is not separate from the "outer" environment and could therefore be described as transcendent (Hyland et al. 2010). In accordance with our findings, Hyland et al. (2010) point out that people usually experience this sense of connection in an all-encompassing way: with regards to nature, places, other people and even the entire universe. This reminds us of Taylor's (1989) description of the wish to re-unify with nature and to feel an 
integral part of a larger order of living things. As the participants described it, experiencing this special connection requires a subtler language of feeling and awareness, which Taylor (1989) refers to as people's powers of expressivity and creative imagination.

Tuning into a special connection with inner/outer nature provides people with purpose in life and a means to reconnect with nature (Pilgrim and Pretty 2010). In terms of Taylor (1989), therefore, the organic philosophy fits in with the Romantic worldview. Campbell (2007) has argued that the popularity of this view is connected with an important shift in the Western worldview, where the belief in a distant, personalized god is slowly being replaced by a belief in an undefined immanent divine force that unites humankind, nature, and the cosmos as one. As a consequence, nature becomes sacred and animals are regarded with reverence, while human superiority and dominion of animal life are discarded (Campbell 2007; Verdonk 2009). Naturally, this shift has profound consequences regarding people's views of food, because their food practices are imbued with meaning and the moral dimension of food choice becomes more salient (Campbell 2007).

This interpretation seems to fit with the Dutch context. The Netherlands has been characterized as one of the most secularized countries in Europe (Knippenberg 1998), but at the same time, strong trends towards contemporary spirituality and religious seekership outside the traditional church have been observed (van Otterloo 1999; Versteeg 2007). Food consumption plays an important role in these trends to maintain a healthy body and mind and to improve oneself spiritually (van Otterloo 1999). This orientation may also explain why participants are not very oriented towards asceticism that played an important role in the Lebensreform and the American Natural Foods Movement but is not mentioned in the literature on contemporary spirituality (Hedlund-de Witt 2011). Nevertheless, while some participants emphasized the religious undertone of their practices, more secular interpretations are also possible and may give rise to the same practices (Hyland et al. 2010). Participants could, for example, equally emphasize the importance of care for animals and nature and the solidarity they feel with other people. In general, it seems that a more value-laden approach to food is in line with the times.

Another key element is that the participants shared their self-determined, moral outlook on life. As Hamilton et al. (1995) put it, food practices of people with this orientation are pervaded by "a concern which goes beyond the material, a desire for a meaningful life, a moral life, one which is in harmony and balance, a desire for mental peace, even perhaps simply contentment and happiness." Gusfield (1992) and van Otterloo (1983) add that this orientation can be understood in the context of the individual that wants to protect her (moral) values against the pressures of civilization. A healthy, natural lifestyle and the discipline to abstain from desires that are constantly aroused by a consumption-oriented environment are experienced as part of the good life. Within this context, the relevance of moral themes, such as purity and temperance with regards to food (Kass 1994; Rozin et al. 1997), is evident, and it also emphasizes the timeliness of the ideas associated with the Reform movements.

A limitation of our study is that our description of organic and natural foods movements in Western countries was supplemented with an analysis of the food philosophy of organic consumers from only one of these countries, The Netherlands. 
This does not enable us to shed more light on the food philosophy of consumers in other Western countries that show similar, but not identical trends of changes in the food system, such as the United States, England and Germany. Although we expect the same basic tension between Enlightenment and Romantic views in these countries, there are many contextual variables that could be important to organic consumers. In particular, differences in transparency between organic and conventional agriculture can be reinforced by contextual factors, such as marketing strategies. In the United States, for instance, organic is framed as a "marketing label," and there seems to be more polarization between the organic and the conventional food chain than in Western Europe (Klintman and Boström 2004). This means that organic consumers may have divergent opinions on the distinctive advantage of organic foods, dependent on the type of market or the maturity of the market in their country (Wier et al. 2008). Future work should examine whether such differences in opinion are also associated with basic differences in food philosophy.

The question now is what is the relevance of the organic food philosophy for a transition towards a more sustainable food system? This question can be addressed at the level of individual behavior, in terms of being an example for conventional consumers, and at the level of social forces, in terms of having an effect on the organization of food systems. As Goodman and Dupuis (2002) note, although organic food consumption is not based on a formal social movement, the philosophies of these consumers appear to constitute a vital force in society. Therefore, the food philosophies can help to interpret societal trends and contextualize ongoing developments. Most importantly, the food philosophies were associated in a theoretically meaningful way with a number of practices that are considered more sustainable than conventional ones, namely the moderate consumption of meat, the choice for seasonal and organic ingredients and the use of less processed and fresh products (Carlsson-Kanyama and González 2009; Thøgersen 2010). This linkage may provide significant cultural leverages - that is, values that motivate people to express concern about environmental and social problems and invite them to adopt more environmentally friendly lifestyles (Crompton 2011).

More specifically, there are at least four leverages that should be mentioned in the Dutch context. The first is cultivating the value of connectedness with nature. The second is cultivating the relationship between awareness and wellness. The third refers to increasing the transparency of moral aspects that are hidden in many food choices. And the fourth is shaping and supporting social norms that reflect the intrinsic value of temperance. In what follows, we discuss some examples of how these leverages could be applied.

Feeling connected with nature contributes to a feeling of responsibility and care for other creatures and the natural environment (Taylor 1989). In the context of making more sustainable food choices, connectedness with nature is a value that needs strengthening, for example, in the context of urban development. Examples of how this can be done are the development of urban agriculture to enable cities to feed themselves from within or from its neighboring communities (Dixon et al. 2009; Morgan and Sonnino 2010). Various big cities, such as New York and London, are already working on food strategies for the future. Trying to localize food production, wherever feasible, is an important component of these strategies 
(Morgan and Sonnino 2010). Also, new supermarket concepts that experiment with growing their products on site are interesting in this regard. More generally, initiatives that strengthen people's knowledge about the multiple links between food and nature, planting, harvesting, and preparation may serve to increase a feeling of connectedness and they are also in line with the wish for a more natural, selfdetermined way of living that was expressed in the Reform movements.

Second, we discussed the value of awareness. As the interviews illustrated, participants experienced independence and self-sufficiency, because they felt they could rely on their personal judgment regarding what is good to eat. This autonomy and the feeling of awareness itself were perceived as satisfying, also because participants felt that they were making choices in line with their personal values. By relying on their intuition and personal values, they felt less prone to external sources of influence, such as advertising. In terms of Taylor's framework, awareness is a crucial part of the expressive worldview, because it is a means to connect with inner/outer nature as a source of morality. Policy makers should acknowledge that this expressivity is a fundamental characteristic of Western culture that also pervades people's relationship with food (Delind 2006). They may profit from this fact by communicating about often implicit underlying values associated with more sustainable food consumption.

Third, we discussed purity as a way of living a more meaningful, moral life (Campbell 2007; Hamilton et al. 1995). The critical, idealistic approach of organic consumers has stimulated the development of environmentally relevant certification and labeling systems, which exerts continuous pressure on producers to raise sustainability standards of their production and supply chains (de Boer 2003; Lewis et al. 2010). Labeling efforts have also served to delineate between conventional and organic standards, providing a visual prompt to facilitate the purchase of more responsible products among a larger group of consumers (Morris and Winter 1999). These labels demonstrate the salience of appealing to moral motives held by a core group in society, increasing the number of people that can make more responsible choices with less effort on their part.

Fourthly, against the background of the organic philosophy, the need for personal behavior change can more easily be acknowledged and achieved. An important part of the Reform movement was about people's capacity for moral self-improvement as a practice of self-determination (Barlösius 1997). Temperance, the consumption of pure foods, and abstinence from meat were all ways in which Reformers practiced their moral values. As the interviews illustrated, these practices are still in use today (de Boer et al. 2007). Policy makers may implicitly or explicitly support social norms that reflect the intrinsic value of temperance. This could be done, for example, by promoting the consumption of large amounts of meat as normatively unacceptable.

\section{Conclusion}

In this study, we have made an exploratory effort to contribute to a better understanding of the cultural context of organic consumption. We have done this by 
trying to combine two levels of analysis: on the one hand, a top-down perspective on long-term developments in Western culture; on the other, a bottom-up perspective on contemporary organic consumers' practices, values, and beliefs. We have identified some important themes relevant to organic consumers today, and we have shown how these are rooted in a typically Western cultural background.

Organic consumption is interesting from the perspective of more sustainable food choices. Despite controversies regarding the expansion of organic production, the organic movement as a whole can be seen as a valuable driving force that stimulates the continuous improvement of food quality and inspires consumers to adopt new values and ideals that can give direction to more sustainable food practices. The feeling of connectedness with nature, awareness and purity are values that can be strengthened culturally in relation to food.

Acknowledgments We would like to thank the anonymous reviewers of an earlier version of this paper for their helpful comments. The lead author also thanks the Rachel Carson Center for Environment and Society in Munich for hosting her as a visiting fellow and providing support for the finalization of this manuscript.

Open Access This article is distributed under the terms of the Creative Commons Attribution License which permits any use, distribution, and reproduction in any medium, provided the original author(s) and the source are credited.

\section{References}

Aertsens, J., Verbeke, W., Mondelaers, K., \& van Huylenbroeck, G. (2009). Personal determinants of organic food consumption: A review. British Food Journal, 111(10), 1140-1167.

Aiking, H. (2011). Future protein supply. Trends in Food Science \& Technology, 22, 112-120.

Alimentarius, Codex. (1999). Guidelines for the production, processing, labelling and marketing of organically produced foods. Rome: FAO.

Badgley, C., Moghtader, J., Quintero, E., Zakem, E., Chappell, M. J., Avilés-Vázquez, K., et al. (2007). Organic agriculture and the global food supply. Renewable Agriculture and Food Systems, 22(02), 86-108.

Badgley, C., \& Perfecto, I. (2007). Can organic agriculture feed the world? Renewable Agriculture and Food Systems, 22(02), 80-86.

Bakker, J. (2011). Monitor Duurzaam Voedsel 2010. Ministry of Economic Affairs, Agriculture and Innovation, The Hague [in Dutch].

Barlösius, E. (1997). Naturgemäße Lebensführung: Zur Geschichte der Lebensreform um die Jahrhundertwende. Frankfurt/Main: Campus Verlag GmbH.

Brown, K., \& Kasser, T. (2005). Are psychological and ecological well-being compatible? The role of values, mindfulness, and lifestyle. Social Indicators Research, 74(2), 349-368.

Buck, D., Getz, C., \& Guthman, J. (1997). From farm to table: The organic vegetable commodity chain of Northern California. Sociologia Ruralis, 37(1), 3-20.

Campbell, C. (2007). The easternization of the West. A thematic account of cultural change in the Modern era: Paradigm Publishers.

Carlsson-Kanyama, A., \& González, A. D. (2009). Potential contributions of food consumption patterns to climate change. The American Journal of Clinical Nutrition, 89(5), 1704S-1709S.

Carson, R. (1962). Silent spring. Boston: Houghton Mifflin Company.

Charmaz, K. (2006). Constructing grounded theory: A practical guide through qualitative analysis. London: Sage Publications Ltd.

Constance, D. H., Choi, J. Y., \& Lyke-Ho-Gland, H. (2008). Conventionalization, bifurcation, and quality of life: A look at certified and non-certified organic farmers in Texas. Southern Rural Sociology, 23, 208-234. 
Crompton, T. (2011). Finding cultural values that can transform the climate change debate. Solutions Journal, 2(4), 56-63.

de Boer, J. (2003). Sustainability labelling schemes: The logic of their claims and their functions for stakeholders. Business Strategy and the Environment, 12(4), 254-264.

de Boer, J., Boersema, J. J., \& Aiking, H. (2009). Consumers' motivational associations favoring freerange meat or less meat. Ecological Economics, 68(3), 850-860.

de Boer, J., Hoogland, C. T., \& Boersema, J. J. (2007). Towards more sustainable food choices: Value priorities and motivational orientations. Food Quality and Preference, 18(7), 985-996.

de Vries, B. J. M., \& Petersen, A. C. (2009). Conceptualizing sustainable development: An assessment methodology connecting values, knowledge, worldviews and scenarios. Ecological Economics, 68(4), 1006-1019.

de Wit, J., \& Verhoog, H. (2007). Organic values and the conventionalization of organic agriculture. NJAS-Wageningen Journal of Life Sciences, 54, 449-462.

Delind, L. (2006). Of bodies, place, and culture: Re-situating local food. Journal of Agricultural and Environmental Ethics, 19(2), 121-146.

Dixon, J. M., Donati, K. J., Pike, L. L., \& Hattersley, L. (2009). Functional foods and urban agriculture: Two responses to climate change-related food insecurity. New South Wales Public Health Bulletin, 20(2), 14-18.

Douglas, M. (1966). Purity and danger; an analysis of the concepts of pollution and taboo. London: Routledge and Kegan Paul.

Fiddes, N. (1991). Meat. A natural symbol. London: Routledge.

Fischler, C. (1988). Food, self and identity. Social Science Information, 27, 275-292.

Foss, D. A., \& Larkin, R. W. (1976). From "The gates of Eden" to "Day of the locust". Theory and Society, 3(1), 45-64.

Glacken, C. J. (1967). Traces on the Rhodian shore; nature and culture in western thought from ancient times to the end of the 18th century. Berkeley, CA: University of California Press.

Glaser, B. G., \& Strauss, A. L. (2009). The discovery of grounded theory (Vol. 4). New Jersey: Transaction Publishers.

Goodman, D., \& DuPuis, E. M. (2002). Knowing food and growing food: Beyond the productionconsumption debate in the sociology of agriculture. Sociologia Ruralis, 42(1), 5-22.

Gusfield, J. R. (1992). Nature's body and the metaphors of food. In M. Lamont \& M. Fournier (Eds.), Cultivating differences: Symbolic boundaries and the making of inequality (pp. 75-103). Chicago: The University of Chicago Press.

Hamilton, M., Waddington, P. A. J., Gregory, S., \& Walker, A. (1995). Eat, drink and be saved: The spiritual significance of alternative diets. Social Compass, 42(4), 497-511.

Hedlund-de Witt, A. (2011). The rising culture and worldview of contemporary spirituality: A sociological study of potentials and pitfalls for sustainable development. Ecological Economics, $70(6), 1057-1065$.

Higgins, E. T. (1997). Beyond pleasure and pain. American Psychologist, 52, 20.

Hodgson, J. A., Kunin, W. E., Thomas, C. D., Benton, T. G., \& Gabriel, D. (2010). Comparing organic farming and land sparing: Optimizing yield and butterfly populations at a landscape scale. Ecology Letters, 13(11), 1358-1367.

Hughner, R. S., McDonagh, P., Prothero, A., Shultz, C. J., \& Stanton, J. (2007). Who are organic food consumers? A compilation and review of why people purchase organic food. Journal of Consumer Behaviour, 6(2-3), 94-110.

Hyland, M. E., Wheeler, P., Kamble, S., \& Masters, K. S. (2010). A sense of special connection, selftranscendent values and a common factor for religious and non-religious spirituality. Archive for the Psychology of Religion/Archiv für Religionspsychologie, 32, 293-326.

IFOAM. (2011). The world of organic agriculture -statistics and emerging trends 2011. Bonn, Frick: IFOAM, FiBL.

Jackson, T. (2005). Live better by consuming less?: Is there a "Double Dividend" in sustainable consumption? Journal of Industrial Ecology, 9(1-2), 19-36.

Jacob, J., Jovic, E., \& Brinkerhoff, M. (2009). Personal and planetary well-being: Mindfulness meditation, pro-environmental behavior and personal quality of life in a survey from the social justice and ecological sustainability movement. Social Indicators Research, 93(2), 275-294.

Jamison, A. (2003). The making of green knowledge: The contribution from activism. Futures, 35(7), $703-716$.

Kass, L. R. (1994). The hungry soul: Eating and the perfecting of our nature. New York: The Free Press. 
Kirchmann, H., Thorvaldsson, G., Bergström, L., Gerzabek, M., Andrén, O., Eriksson, L. O. (2008). Fundamentals of organic agriculture - past and present. In H. Kirchmann \& L. Bergström (Eds.), Organic crop production-ambitions and limitations (pp. 13-37). The Netherlands: Springer.

Klintman, M., \& Boström, M. (2004). Framings of science and ideology: Organic food labelling in the US and Sweden. Environmental Politics, 13(3), 612-634.

Knippenberg, H. (1998). Secularization in The Netherlands in its historical and geographical dimensions. GeoJournal, 45(3), 209-220.

Kristiansen, P., \& Merfield, C. (2006). Overview of organic agriculture. In P. Kristiansen, A. Taji, \& J. Reganold (Eds.), Organic agriculture: A global perspective (pp. 1-23). Collingwood, Australia: CSIRO Publishing.

Lang, T., \& Heasman, M. (2004). Food wars. London: Earthscan.

Lewis, K. A., Tzilivakis, J., Warner, D., Green, A., McGeevor, K., \& MacMillan, T. (2010). Effective approaches to environmental labelling of food products. Appendix A: Literature review report. London: Department for Environment, Food and Rural Affairs (Defra).

Montanari, M. (2006). Food is culture. New York: Columbia University Press.

Morgan, K., \& Sonnino, R. (2010). The urban foodscape: World cities and the new food equation. Cambridge Journal of Regions, Economy and Society, 3(2), 209-224.

Morris, C., \& Winter, M. (1999). Integrated farming systems: The third way for European agriculture? Land Use Policy, 16, 193-205.

Naugle, D. K. (2002). Worldview: The history of a concept. Cambridge: Wm. B. Eerdmans Publishing Co.

Pilgrim, S., \& Pretty, J. N. (2010). Nature and culture: An introduction. In S. Pilgrim \& J. N. Pretty (Eds.), Nature and culture. Rebuilding lost connections. London: Earthscan.

Raynolds, L. T. (2004). The globalization of organic agro-food networks. World Development, 32(5), 725-743.

Reijnders, L., \& Soret, S. (2003). Quantification of the environmental impact of different dietary protein choices. The American Journal of Clinical Nutrition, 78(3), 664-668.

Rozin, P., Markwith, M., \& Stoess, C. (1997). Moralization and becoming a vegetarian: The transformation of preferences into values and the recruitment of disgust. Psychological Science, $8(2), 67-73$.

Scherr, S. J., \& Sthapit, S. (2009). Mitigating climate change through food and land use. Washington: Worldwatch Institute.

Schifferstein, H. N. J., \& Oude Kamphuis, P. A. M. (1998). Health-related determinants of organic food consumption in The Netherlands. Food Quality and Preference, 9, 119-133.

Schultz, P. W., Shriver, C., Tabanico, J. J., \& Khazian, A. M. (2004). Implicit connections with nature. Journal of Environmental Psychology, 24(1), 31-42.

Small, M. L. (2009). How many cases do I need? Ethnography, 10(1), 5-38.

Stehfest, E., Bouwman, L., van Vuuren, D., den Elzen, M., Eickhout, B., \& Kabat, P. (2009). Climate benefits of changing diet. Climatic Change, 95(1), 83-102.

Taylor, C. (1971). Interpretation and the sciences of man. The Review of Metaphysics, 25(1), 3-51.

Taylor, C. (1989). Sources of the self: The making of the modern identity. Cambridge: Harvard University Press.

Thøgersen, J. (2010). Country differences in sustainable consumption: The case of organic food. Journal of Macromarketing, 30(2), 171-185.

Tilman, D., Fargione, J., Wolff, B., D’Antonio, C., Dobson, A., Howarth, R., et al. (2001). Forecasting agriculturally driven global environmental change. Science, 292(5515), 281-284.

van Otterloo, A. H. (1983). De herleving van de beweging voor natuurlijk en gezond voedsel. Sociologisch Tijdschrift, 10, 507-545.

van Otterloo, A. H. (1999). Selfspirituality and the body: New age centres in The Netherlands since the 1960s. Social Compass, 46(2), 191-202.

Verdonk, D. J. (2009). Het dierloze gerecht: Een vegetarische geschiedenis van Nederland. Amsterdam: Uitgeverij Boom.

Versteeg, P. (2007). Spirituality on the margin of the church: Christian spiritual centres in The Netherlands. In K. Flanagan \& P. C. Jupp (Eds.), A sociology of spirituality. Hampshire, England: Ashgate Publishing Limited.

Vogt, G. (2007). The origins of organic farming. In W. Lockeretz (Ed.), Organic farming: An international history. Oxfordshire: CAB International. 
Weiss, R. (1994). Learning from strangers. The art and method of qualitative interview studies. New York: The Free Press.

Wier, M., O’Doherty Jensen, K., Andersen, L. M., \& Millock, K. (2008). The character of demand in mature organic food markets: Great Britain and Denmark compared. Food Policy, 33(5), 406-421. Yin, R. K. (2003). Applications of case study research. California: Sage. 